\title{
ANALYSING TRADE-OFFS IN MANAGEMENT DECISION- MAKING BETWEEN ECOSYSTEM SERVICES, BIODIVERSITY CONSERVATION, AND COMMODITY PRODUCTION IN THE PERUVIAN AMAZON NATIONAL RESERVE
}

\author{
Diego Hopkins, Zen Makuch, Karen Makuch \\ Imperial College London, United Kingdom. \\ *Corresponding Author Email: d.hopkins17@imperial.ac.uk
}

This is an open access article distributed under the Creative Commons Attribution License, which permits unrestricted use, distribution, and reproduction in any medium, provided the original work is properly cited

\section{ARTICLE DETAILS}

\section{Article History:}

Received 02 February 2019

Accepted 04 March 2019

Available Online 07 March 2019

\section{ABSTRACT}

The Ecosystem Services concept has been developed in recent decades through both academic and international institutions. Nowadays, most of the literature agrees that ecosystem services constitute a crucial contribution to human well-being. Most studies focus on final ecosystem services which are directly identifiable amongst society's consumption habits. Ecosystem services generally named "Provisioning Services" seem to be the masterpiece of ecosystem services provided by nature, and their contribution to human well-being is linked to their economic relevance. In most cases this can be easily determined as there are markets already developed to evaluate these services. Nonetheless, final ecosystem services are supported by often-overlooked Intermediate Ecosystem Services, which do not have a structured market and yet hold an economic relevance thatcould directlyaffectsociety.Similarly, cultural ecosystem services are often difficult to economically assess as it isvery difficult to puta price on intrinsic values. Though Regulating and Cultural Ecosystem Services are difficult to value, they are of vital importance to society and must be evaluated when making any assessment locally or regionally. In order to yield a better understanding of the importance of all ecosystem service categories, we propose a spatial-temporal limited study to pinpoint the synergies and trade-offs between Ecosystem services, Biodiversity conservation, and Commodity production in Allpahuayo Mishana National Reserve, and to highlight the possible environmental and economic outcomes accordingtodifferent management scenario

\section{KEYWORDS}

Provisioning Services, consumption habits, Intermediate Ecosystem Services

\section{INTRODUCTION}

In recent decades, a large amount of research has been devoted to highlighting the importance of ecosystem services' contribution to human well-being [1]. The utility of ecosystem services has often been linked to the economic role they play for society. Nonetheless, it has been demonstrated that although the use of ecosystems has led to an increase inhuman well-being, some advances have been made at the cost of other services that are essential for society $[2,3]$.

The current globalized economy arguably promotes a global reduction in ecosystem integrity and ecosystem services [4]. We must bear in mind that we live in a world of scarcity and that we ought to make choices about the correct management of ecosystem services, (the point of assessments) to find a fair trade-off between benefits and impacts [5].

One of the most important and useful tools for possible future scenarios and make making the land use management choices is economic valuation. Economic valuation is also useful in compensation mechanisms as ecosystems provide benefits to people. Ideally, the partial or full destruction of an ecosystem should be accompanied by the compensation of the corresponding benefits [6]. Economic valuation enables policymakers to evaluate different environmental assets and scenarios using the same economic indicators that provide useful comparisons to assess alternatives. It is important to state that expressing values in monetary units does not imply privatisation or market exchanges, as most ecosystem services are non-excludable, and therefore poorly fit into markets [7].

Even when economic valuation might contribute to land management assessment, in scientific literature the use of economic valuation is isolated, with few exceptions. Often economic valuations are presented, then proposed as being useful for decision making, yet without the use being contextualised, and without concrete examples being provided nor analysed [8].

Ecosystem service analyses have been applied to raise awareness of the economic benefits provided by ecosystems and to analyse the costs and benefits of different management options, but this needs to be applied in concrete management decisions for the study áreas [9]. Practical applications of the ecosystem service concept are necessary to make it an acknowledged tool for natural resource management [10].

\subsection{Aims and Objectives of this Work}

Noting that land use management decisions often involved ecosystem service trade-offs we explore the extent to which synergies among ecosystem services can inform decisions before trade-offs take place. Such an approach may improve decision-making where otherwise, 
stakeholders may well differ widely in their assessment of the ecological, social and economic benefits of ecosystem services which align with stakeholder land use preferences.

From an orthodox financial perspective, loss of some services may be negligible and hence, acceptable though environmental and social losses can be significant [11]. For this reason, and to achieve better integrated land use management solutions, in this paper, we undertake the following:

- A limited spatial-temporal economic study in the Peruvian Amazon, more specifically in Allpahuayo Mishana National Reserve (AMNR), based on the evaluation of provisioning, regulating, and cultural ecosystem services. We have done so for the AMNR taking account of its economic relevance to the national economy and its corresponding regional relevance in the surrounding area;

- A mapping exercise which traces the consequences of the application of different management decisionshighlighting the biophysical trade-offs between scenarios; and,

- Analyis of the AMNR indigenous community perceptions about possible development outcomes with the revelation that monetary considerations are not the only factors worth considering.

For local or regional decision-making processes, tradeoffs between particular ecosystem services need to be calculated [10]. One of the objectives of this paper is to study the trade-offs between different ecosystem services under two different scenarios, to obtain the possible outcomes of land management decisions for Allpahuayo Mishana National Reserve (AMNR). The other main objective is to demonstrate that, far from obtaining information about tradeoffs, AMNR management decisions could produce "synergies", defined as a situation where the use of one ecosystem service directly increases the benefits supplied by another service [12].

In this regard, it is important to bear in mind that determining ecosystem service's supply, demand, spatiotemporal distribution, and their integration into planning processes is vital for achieving effective outcomes that could be widely accepted by stakeholders [13]. Therefore, synergistic outcomes may be more beneficial than tradeoffs as they may satisfy a broader range of stakeholders.

\subsection{Categorisation of Ecosystem Services}

Some researchers group ecosystem services on final/end services (services that directly benefit people) (REF), and intermediate services (regulating and supporting) [14]. Promising attempts have been made for defining and categorising ecosystem services, for instance - The Economics of Ecosystems and Biodiversity 2010, the Millennium Assessment 2005, or The Common International Classification of Ecosystem Services 2011. In this study, we are going to use an approach based on the most commonly applied three ecosystem service categories: Provisioning, Regulating, and Cultural services.

What we find in the next two sub-sections is the elaboration of two main focal points which colour our research methodology, results and analysis. They include "ecological integrity" and "trade-offs".

\section{ECOLOGICAL INTEGRITY AND REGULATING, PROVISIONING AND CULTURAL ECOSYSTEM SERVICES}

Fundamental to our research is the principle that ecological integrity is the base for the supply of regulating, provisioning, and cultural ecosystem services [15]. The ecological integrity concept refers to the ecosystem composition features that provide for optimal conditions in a specific geographic region. Hence, ecological integrity exists when an ecosystem possesses all of the native biodiversity and ecological processes that a regional habitat should contain, providing the conditions to native species to reproduce sustainably [16].

The regional supply of ecosystem goods and services is directly determined by the regional ecological integrity which is influenced by human's actions and decisions such land cover change, land use and technical progress [10]. Regarding this, land use change affects the variety, quantity, and spatial distribution of regulating ecosystem services throughout time, and also might affect provisioning cultural ecosystem services, as alterations can lead to increasing or decreasing supplies of selected bundles of ecosystem services on which society depends $[17,18]$.

There is an economic relevance potential in this region as forests and/or tree-based land- use/land-cover had the greatest ability to provide higher ecosystem services and multiple ecosystem services components in protected areas [13]. When landowner decisions are based solely on market returns, they will tend to generate land- use/land-cover patterns with lower provision of ecosystem services and biodiversity conservation, as they focus on immediate economic return at expense of environmental conditions [19]. The different land covers within AMNR provide several ecosystem services, thus, it is crucial for the correct functioning of ecosystems that ecological conditions are suitable for the provision of services and goods.

\section{TRADE-OFFS BETWEEN ECOSYSTEM SERVICES}

In the 21st century, we are facing several pressing and interrelated problems including large-scale conversion of ecosystems and the subsequent loss of biodiversity [20]. Therefore, it is vital to assess ecosystems and their capacity to produce services. Ecosystem services have great potential to influence environmental decisions because they link ecosystem functions and conditions to anthropocentric interests that resonate on society [14].

Ecosystem service trade-offs arise from management choices made by humans, which can change the type, magnitude, and relative mix of services provided by ecosystems [21]. Three key indicators are determinants to understand whether or not a trade-off will occur: 1. Private interest in one or more ecosystem service, with the winner having a private interest, and the loser a public interest; 2 . the dominating presence of Provisioning services, having the winner benefit from this, with the loser having a broader profile of ecosystem services; and 3. participation of one of the stakeholders, particularly the winner, at the local scale, taking into consideration that losers typically had a more mixed profile in terms of the scale at which they were acting [22].

Assessment of ecosystem services and integration of their value into the economy and decision making were recently one of the most important fields of scientific work, but studies on synergies and trade-offs between ecosystem services at the local scale are required to highlight the role of landscape management $[4,23]$. Trade-offs involving ecosystem services imply either implicit or explicit valuation, the last one allowing the units of all the elements to be expressed in the same common denominator to allow direct comparison of the tradeoffs [7]. It is relevant to produce outcomes expressed in monetary terms in order to give a better idea of the economic consequences for the study area, besides the effects on the functioning of the ecosystem due to land use.

By analysing plausible future scenarios for AMNR, we would determine not only the biophysical and economic consequences, but also the tradeoffs between ecosystem services, as the assessment enables us to appreciate the synergies between ecosystem services which will enrich management decisions. Targeting land management to optimise naturebased solutions can help to make more efficient use of synergies between multiple ecosystem services to tackle the challenges of the future [17].

This analysis is especially important in developing countries as depreciation of natural capital is particularly high in developing economies, which are often rich in resources and ecosystems. Actually, the decline in natural capital has been five times greater on average in developing economies compared to rich countries [24].

\section{METHODOLOGY}

\subsection{Context: The Allpahuayo Mishana National Reserve (AMNR)}

The Allpahuayo Mishana National Reserve (AMNR) is a Protected Area located in Iquitos, capital city of Loreto, Peru (Figure 1). Loreto is the biggest province in Peru and covers almost all the Amazonian lands in the country.

Allpahuayo Mishana was declared National Reserve by Supreme Decree 002-2004-AG in 2004, with the objective of preserving biodiversity and 
habitats of varillal and chamizal above white sand, and the flooded forest on Nanay river basin. AMNR presents three main land-covers: Varillal forest, Tahuampas, and Highland forest. Not considering intervened areas, these land- covers comprehend 51,952.2 hectares of the national reserve, representing $9.17 \%, 30.93 \%$, and $49.37 \%$ respectively.

The study area has been selected as it is very vulnerable to the consequences of inappropriate land management decisionsREF. Demand for agricultural and forest commodities creates conflicts and trade-offs between conservation and production, particularly in tropical countries [13]. Efforts to set aside new lands for biodiversity conservation in tropical regions are compromised by the rising demand for food, timber and other products [25].

It is important that options and preferences representative of the entire population of direct users of the ecosystem be obtained and considered when making the assessment of the study area [26]. This would provide information on demand, which is very important not only on the assessment itself but also when producing the economic outcomes and the design of the future scenarios.

One important component to be analysed when obtaining the trade-offs between ecosystem services is the capacity of the ecosystem to produce determined services according to the land- covers studied, to determine if this capacity is affected at the expense of the reduction or improvement of other ecosystem service capacity. This concept must be understood as the ability of the ecosystem to generate a basket of ecosystem services under current conditions and uses at the maximum sustainable yield that does not lead to a decline in conditions of the ecosystem. For instance, high capacity to generate timber would be negatively correlated to the ecosystem's capacity to sequester carbon or support tourism [27].

Since the use of one function may influence the availability of other functions, goods and services, the capacity of the ecosystems to provide goods and services should be determined under complex systems conditions [28]. Thus, biophysical conditions play a crucial role in delivering ecosystem services but are often overlooked. The value of intermediate services is not apparent until the declines cause problems for other measured services [14].

As ecosystems are complex mechanisms that contribute to providing environmental goods and services to society, it is needed to be assessed on a dynamic manner, considering all the variables that might affect the provision of ecosystem services. The integration of supply and societal needs for goods and services enhances currently applied functionoriented landscape planning approaches and environmental management strategies [18].

Beside the correspondent classification, we are going to use purely naturebased ecosystem services which do not require human intervention to produce economic benefits. Firstly, because additional anthropocentric inputs need to be distinguished from natural inputs, otherwise we might be dealing with human- modified systems because of the intensive use of non-nature inputs [29]. Secondly, human intervention often causes a good supply of ecosystem services, but not necessarily reflects a good ecosystem capacity [27].

In order to get the real ecosystem capacity, we are going to assess naturebased ecosystem services, using potential supply as indicator of the flow of the service and demand as a driver that should be analysed to project future scenarios to develop environmental management measures which ensure the future provision of environmental goods and services following a more sustainable model.

\subsection{Stakeholder Surveys, Interviews and Meetings}

Eight indigenous communities are settled inside AMNR. These communities are in permanent communication with the National Service for Protected Areas in Peru (SERNANP), which is responsible for monitoring the economic and extractive activities held by the communities inside AMNR. The indigenous communities are: San Martin, Mishana, Yuto, El Porvenir, 15 de Abril, Anguila, Agua Blanca, and Nueva Esperanza. responses by experts' element contemplated in the Delphi method developed by using responses directly obtained from indigenous communities [30]. We state here that indigenous persons are 'experts' and guardians of their own environment, having lived and worked with it for centuries. It is important to state that all the participants consented to the surveys and photos used in part of this research by signing consent forms provided by the authors.

The stakeholders from San Martin, Mishana, Yuto, El Porvenir communities, the ranger stations Yarana and Irapay (Figure 2), and the National Reserve professional staff were selected based on their familiarity with AMNR, and their knowledge of the benefits arising from different land-covers [13].

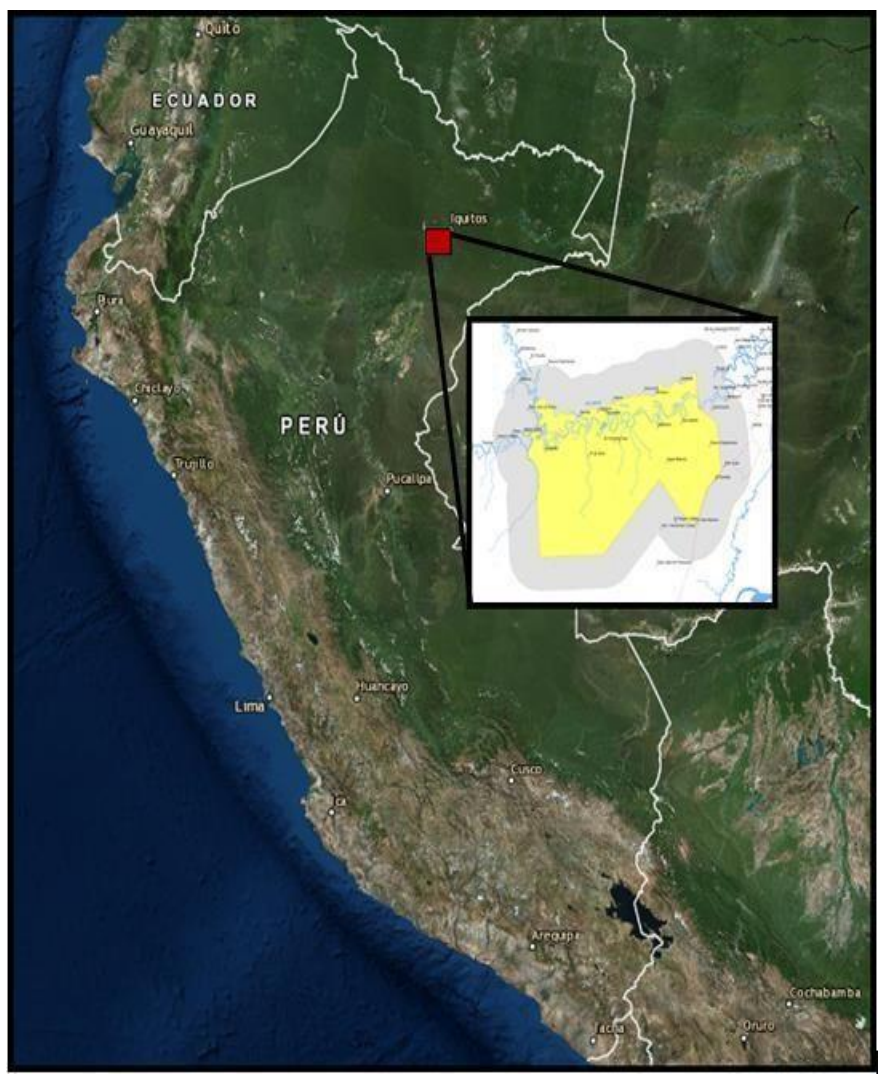

Figure 1: Allpahuayo Mishana National Reserve Map

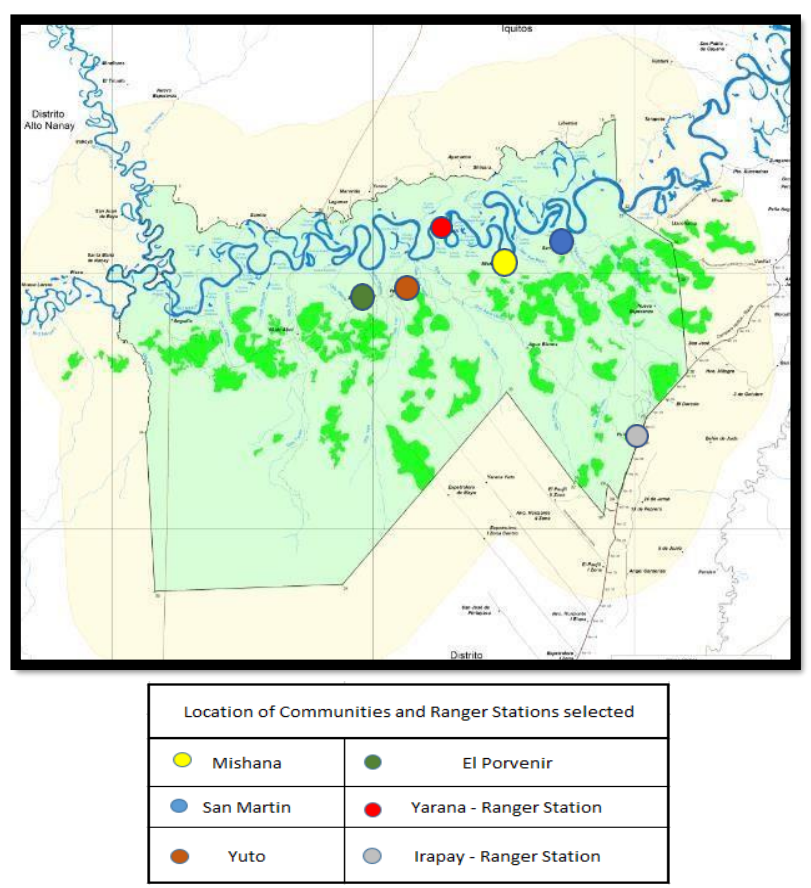

Figure 2: Location of Indigenous Communities and Ranger Stations 
Information was obtained from four indigenous communities and two ranger stations inside AMNR, and professional staff in charge of the administration of the national reserve (Table 1). The information collected was focused on land covers the highest capacity to produce determined ecosystem services. In this study, we assessed four provisioning services: 1. Aguaje, 2. Ungurahui, 3. Round wood, and 4. White Sand, one regulating service; 1 , carbon sequestration, and two cultural services 1 . biodiversity, and 2. recreational values).

Our Delphi technique is based on the organisation of workshops with the local stakeholders, organised for identification, assessment, and scoring of ecosystem services from individual Land use and Land covers in AMNR [13]. Local concerns ensure that the outputs would be of practical use and have management relevance [31].

Table 1: Stakeholders selected for the assessment

\begin{tabular}{|l|c|}
\hline \multicolumn{1}{|c|}{ Stakeholder category } & Number \\
\hline Mishana community & 3 \\
\hline San Martin community & 3 \\
\hline El Porvenir community & 3 \\
\hline Yuto community & 3 \\
\hline Allpahuayo Mishana National Reserve - Proffesional Staff & 2 \\
\hline Yarana ranger station & 2 \\
\hline Irapay ranger station & 1 \\
\hline Total & $\mathbf{1 7}$ \\
\hline
\end{tabular}

The Framework for Participatory Impact Assessment is considered as it comprised a preparation phase and a regional stakeholder workshop, needed in this case to obtain accurate outcomes that are not biased by lack of information or misleading definitions about ecosystem services theoretical concepts [32].

\subsection{Assessment and Scoring exercise}

The assessment of the supply potential of AMNR was conducted through surveys with indigenous communities within the national reserve. The participants were selected based on the knowledge they have about the environmental conditions and supply potential of the ecosystem services in the three land-covers: 1. Varillal forests, 2. Tahuampas (flood forests), and 3. Highland forests.

They were asked to assign a value from 0 to 5 to the different land-covers according to its capacity to provide the selected ecosystem services, being 0 the value for no potential capacity to supply the ecosystem service, and 5 being the highest score to indicate a high provision capacity.

\subsection{Scenarios}

These ecosystems are threatened by mining concessions on white sand on the buffer zone. AMNR is very rich in white sand, thus, one of the scenarios we evaluated was the Development scenario in which we assumed a highintensity exploitation of white sand within the national reserve.

Problems emerge when goods and services go through long supply chains from providing units to traders before the end product reaches the final consumer [18]. For this reason, we obtained information directly from the communities which are the final users of the ecosystem services studied.

We assessed AMNR under two different scenarios:

- 1. Conservation scenario.- Under this scenario, commodity production will be null, and all the land management decisions are going to be related to enhancing habitats and conservation of the ecosystem.

- 2. Development scenario.- This scenario will assume that national policies implemented in the next twenty years would focus on the intensification of the exploitation of white sand.

This analysis highlights the economic and biophysical consequences of different land-use scenarios. The scenario planning is defined as a structured process of exploring and evaluating alternative futures, being its goal to illustrate the consequences of drivers and policy options, and improve land management decisions, allowing us to make a direct comparison to better appreciate the trade-offs [7].

These scenarios are projected to 2038. This study is framed within a twenty year time scale based on the fact that rehabilitation of ecosystems may take from 20 to 25 years, even when they do not necessarily follow a predetermined trajectory, thus, it would be the time needed to restore the ecosystem lost whether we start white sand exploitation policies to run from 2018 [11].

\section{RESULTS}

Based on the information provided by the stakeholders regarding the identification, assessment, and scoring of the land-covers' capacity to provide provisioning, regulating, and cultural ecosystem services selected, we processed the results and obtained a score matrix that describes the supply potential within AMNR (Table 2). Provisioning services, which concentrate all the economic activities in and around the national reserve, have the lowest supply potential according to stakeholders, while Cultural Ecosystem services represent the greatest supply potential in AMNR.

Regarding the land-covers, the highland forest has the greatest supply potential, while Tahuampas or flood forest has the lowest. Even with some differences, all land-covers present a great supply potential respect to cultural and regulating ecosystem services, which can generate a crucial synergy between ecosystem services to obtain better and more sustainable environmental and economic outcomes for the communities. According to the score matrix obtained after the assessment, we were able to identify the areas within the national reserve that could be exploited following a different path (Figure 3).

To design a new management plan, the national reserve authorities must identify the areas that have the potential to provide ecosystem services that communities consider less harmful to their environment. Results demonstrate that there is a need for diversification of economic activities and analysis of the options to obtain future revenues must be considered too, as following the same path will only continue the exploitation of the natural resources within AMNR, which leads to degradation of land-covers and ecosystem capacity to provide services and goods.

Table 2: Assessment matrix illustrating the supply capacity of different land cover classes to provide ecosystem services.

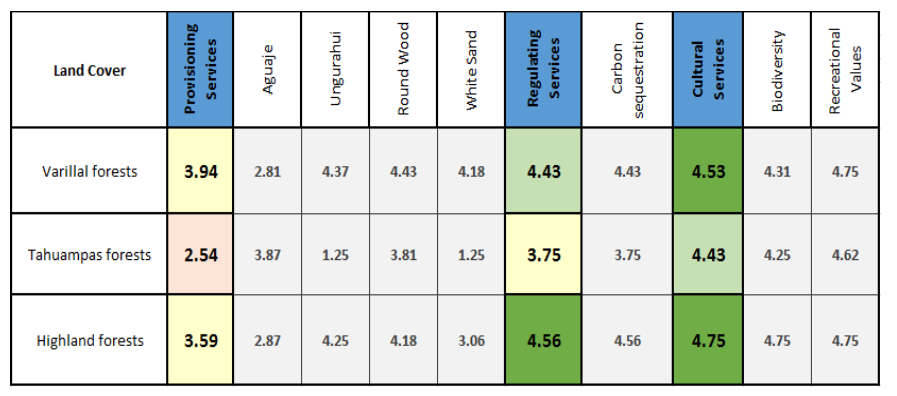




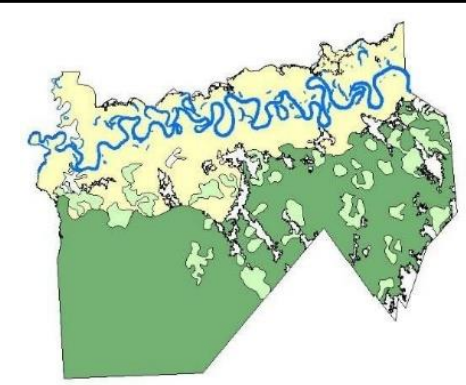

Regulating Ecosystem Service potential

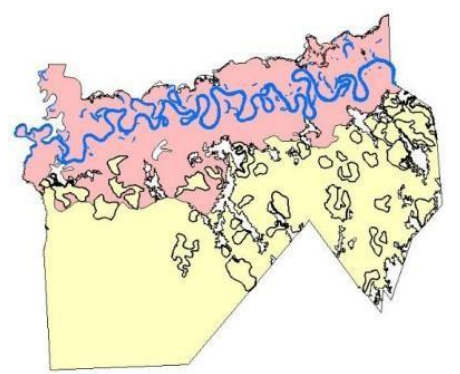

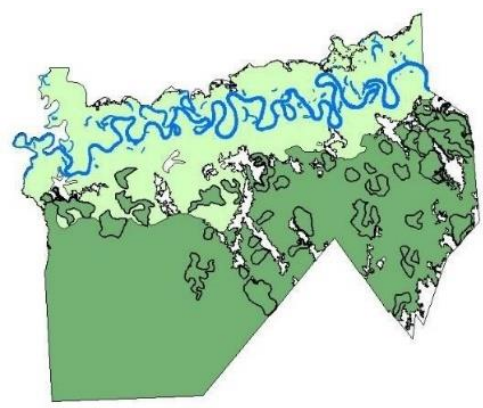

Cultural Ecosystem Service potential

Provisioning Ecosystem Service potential

Figure 3: Spatial distribution of Ecosystem Services supply according to Land-covers

\subsection{Provisioning ecosystem services}

\subsubsection{White Sand}

An important area of the national reserve is covered by white sand, which represents a great supply potential for the exploitation of this mineral. Nonetheless, the consequences of its exploitation can bring several tradeoffs between ecosystem services, which leads to degradation of landcovers.

White sand mining concessions are operating within the buffer zone of the national reserve (Figure 4), affecting considerably the environment and the ecosystem, diminishing its capacity to provide services andgoods. White sand exploitation is the most profitable economic activity around AMNR and could be very profitable for the communities within the national reserve but at the expense of biodiversity and environmentalquality.
Regarding the revenues from white sand, $18 \mathrm{~m} 3$ cost approximately $\$ 278.63$. Taking into account that the extraction of this mineral could reach $60 \mathrm{~m} 3$ a day, in a year it can generate more than $\$ 300,000$. Although, this revenue is obtained at expense of environmental quality in the buffer zone of a national reserve, most of the profit goes to private hands, leaving the communities with no money in their pockets.

Considering the average change of prices indicators provided by the Institute of Statistics and Information of Peru (INEI) for the construction sector on the last years, the exploitation of white sand, if we consider the same amount of extraction based only in just one mining concession, can reach more than $\$ 370,000$ by 2038 . The AMNR potential would exceed in a significant mean the revenues obtained by this private concession, but again at the expense of the other ecosystem services and degradation of land-covers.

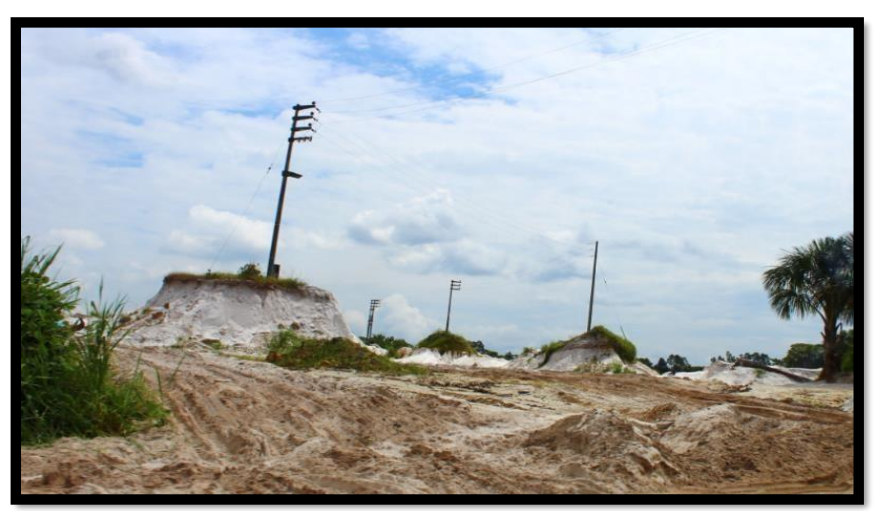

Figure 4: White sand mining concession in AMNR buffer zone

\subsubsection{Ungurahui, Aguaje, and Round wood}

Within AMNR, the extraction of Ungurahui and Aguaje is monitored by the SERNANP, and it is extracted mainly for direct consumption from the community and for sale in minor scale in the markets around Iquitos. Unlike white sand concessions, ungurahui, aguaje, and round wood are directly extracted by families from the communities inside the national reserve, and the revenues obtained, even when they are very low, they remain within the communities.

According to the last monitoring reports obtained from SERNANP, aguaje and ungurahui represent an average income of $\$ 11,475$ a year. The families which effectively extract and sell the products are beneficiaries of the incomes reported. Based on information provided from INEI, and taking into account the annual price variation for these products which is around $0.51 \%$, and considering the $3.16 \%$ reported last year regarding the cumulated price variation for 2017, using as a baseline 2011, the price that non- timber products could reach under the conservation scenario is almost $\$ 12,700$ a year by 2038 , divided between the families that effectively extracted and sold the product.

Regarding round wood, communities obtain an average amount of 
$\$ 12,616$ a year, based on information provided by SERNANP through its monitoring reports. Under the conservation scenario, the trend would lead the communities to obtain almost $\$ 14,000$ a year from the exploitation of round wood within AMNR by 2038.

\subsection{Regulating Ecosystem Services}

\subsubsection{Carbon stock estimates}

Currently, carbon sequestration projects are not implemented within AMNR, and there are no plans for developing one. There is a lack of information regarding the economic outcomes that these projects could generate to the communities. Following the conservation scenario, communities would also be able to develop carbon sequestration projects, receiving equally the revenues obtained for the preservation activities the conduct.

The estimates of carbon stocks are determinant to calculate the revenues that AMNR could generate through the implementation of a carbon sequestration project. In many cases the biomass from trees has been used to calculate the carbon stored through the multiplication of the available quantity within determined area by a factor from 0.40 to 0.55 , due to findings about the proportion of carbon stored in any vegetal species. Nonetheless, in this study, the carbon stocks were calculated based on the average outcomes obtained in studies regarding carbon stored in the region.

Using carbon density values (Mg C ha-1), Peru stocks on average $157 \mathrm{Mg}$ C ha-1, amount that was calculated from the ratio of total carbon to total forest area at national or regional level, also considering canopy cover thresholds of $10 \%, 25 \%$, and $30 \%$ [33]. This study is used by the Agriculture, Forestry and Other Land Use Carbon Calculator developed by the United States Agency for International Development (USAID). In another case study, developed in the Biological station of the Research and Capacitation Centre Rio Los Amigos (CICRA), the total amount of carbon stored within the area of 2977.896 ha was $776603.28 \mathrm{Mg} C$ ha-1, being the average per hectare $260.79 \mathrm{Mg} \mathrm{C}$ ha-1 [34].

Los Amigos Conservation concession has also been studied, and the results show carbon storage of $173 \mathrm{Mg} \mathrm{C}$ ha-1 [35]. Martel \& Caraipoma argue that the difference between the results was based on the diversity of vegetation studied by Winrock, which are not found at the CICRA. Although the results obtained by Winrock International are lower than other studies, we must consider that data from Los Amigos Conservation Concession were not representative of forest nationally [35]. Thus, forest to the north and south of this local study area are estimated to contain between $20-35 \%$ less carbon per unit area, which results in carbon stocks of 112.4 to $138.4 \mathrm{Mg}$ C ha-1 [36].

The value depends on a large number of factors including: tree species, age, whether the trees are thin or not, and on external factors that can affect the growth and life of the tree [37]. Considering this, affirmed that the Amazon forest, in more fertile and flat Holocene alluvial surfaces, supports 110 to $125 \mathrm{Mg} \mathrm{C}$ ha-1. Based on the information obtained, the average carbon stocks of the Amazonian region results in $153.79 \mathrm{Mg} \mathrm{C}$ ha1. This amount of carbon stored per hectare was used to calculate the revenues of carbon projects within AMNR.

\subsubsection{Carbon market price}

Carbon reduction credits, also known as carbon offsets, are an effective cost-containment mechanism and have the potential to produce greenhouse gas reductions alongside a variety of co-benefits [38]. Precisely these co-benefits are needed by communities within AMNR. Currently, the price paid for carbon offsets in Latin America is $\$ 3.8 / \mathrm{tCO} 2 \mathrm{e}$, whilst for forestry and land use projects the price is $\$ 5.1 / \mathrm{tCO} e$ e According to the global carbon market, and across all attributes, the average price is $\$ 3 / \mathrm{tCO} 2$ e [39]. This price is substantially lower than the price levels that are consistent with achieving the temperature goal of the Paris Agreement, in the range of $\$ 40$ to 80 /tCO2e in 2020 [40]. Varillal forests, Highland forests, and Tahuampas (flood forests) cover 51,952.2 hectares, which could store approximately $7.9 \mathrm{MtCO} 2 \mathrm{e}$, according to our calculations. Based on this information, a carbon offsetting project could generate an impressive improvement in revenues for communities inside the national reserve.
It is important to mention that Latin America sold 6.7 MtCO2e in 2015, and $5.8 \mathrm{MtCO2e}$ in 2016 [39]. For this reason, it is not realistic to multiply the average price by the carbon stored in AMNR. The selling of carbon offsets covered 1.5 MtCO2e in Peru in 2015 [41]. Considering this information, the selling of $1 \mathrm{MtCO2e}$, and based on the average price across all attributes for carbon credits, we estimate that AMNR could receive around $\$ 3$ million for the implementation of the project, not exploiting its maximum carbon capacity, which would economically benefit the national reserve until 2020 when it is expected that the prices for carbon offsets would rise, and the revenues would increase considerably. The actual land use/land cover pattern that emerges under a carbon market will depend on the prices paid for sequestration, which carbon pools are eligible for payment, and the individual preferences of landowners [19]. All these features must be considered by decision-makers for correct implementation and fair redistribution of benefits between communities.

To achieve such benefits, it is required to have a better understanding of how carbon dioxide, climate and other 'indirect' anthropogenic factors are actually affecting old growth forests. This requires a significant increase in the level of investment in tropical forest monitoring, combining groundbased and remotely-sensing techniques, especially so in protected areas [42]. It is also important to take into account that shorter harvest cycle may produce lower carbon sequestration rates [17]. For this reason, a collaboration between authorities and communities within the national reserve is vital for the success of a carbon offset project. Under this conservation scenario, carbon offsetting is a great first step to build a new development path that could be a focus on tourism and conservation of biodiversity, obtaining benefits from cultural ecosystem services.

\subsection{Cultural Ecosystem Services}

\subsubsection{Biodiversity and Tourism}

There is a solid, growing body of empirical evidence on how different components of biodiversity underpin ecosystem conditions and processes that influence ecosystem service provision [43]. AMNR would not be capable to develop a tourism project with a degraded ecosystem, as this would affect biodiversity and viceversa.

Evidence suggests that high levels of biodiversity are necessary to maintain multiple processes at multiple locations and over time, which might affect provisioning, regulating, and cultural ecosystem services at the same time [44]. In the current scenario, the contribution from tourism of AMNR to local economies was around $\$ 247,500$ in 2016 . The national reserve registered 2,399 tourists, being 157 international visitors, and 2,242 nationals [45].

Under the conservation scenario, with communities focused on preservation of ecosystems within AMNR, the tourist flow could increase. For instance, Pacaya Samiria National Reserve, which is near to AMNR but further away from Iquitos, received 10,940 visitors in 2016, from which 9,982 were international, and only 958 nationals. Pacaya Samiria National Reserve contributed to local economies with $\$ 6,257,879$ [45]. AMNR has the potential to develop an important tourism project based on their ecosystems and biodiversity conservation, and the closeness to Iquitos, the capital city of Loreto.

\section{CONCLUSION}

Our research has revealed that the sole pursuit of market opportunities (e.g., white sand concessions, ungurahui, aguaje and round wood sales) for the development of nature reserves tends to undermine ecological integrity and a range of Regulating and Ecosystem services. Equally, a unilateral focus upon provisioning services tends to conceive of land use management decisions along lines which require trade offs which pit economic gains against ecosystem functionality with adverse environmental and sociocultural consequences.

What we have learned about the Allpahuayo Mishana National Reserve in particular is that it has a great potential capacity to provide Regulating and Cultural ecosystem services. In fact, according to our assessment matric, Regulating and Cultural services-derived options provided for greater supply capacities for ecosystems services. Nonetheless, Provisioning services currently generate the main total amount of incomes for the indigenous communities within the national reserve. For this reason there 
is a lack of knowledge regarding the implementation of other options which might generate more benefits to local communities.

Regulating ecosystem services constitute the best option for AMNR to build the first step to transforming its economic path into an environmentally sound source of revenues consistent with ecosystems integrity. Through conservation measures the ecosystem services will maintain their supply capacity while allowing AMNR to develop a carbon sequestration project, which would generate more revenues than following the current economic path.

One of the most valuable outcomes we obtained through this research is that there will be no need for economic or environmental tradeoffs if communities decide to conserve their ecosystems. Regulating and Cultural ecosystem services generate synergies between them and both acquire economic relevance as they will generate lasting, sustainable revenues for communities in the long term at the time that they preserve the environment, ensuring the maintenance of ecosystem functionality.

Revenues from the development of a carbon sequestration project should be considered at least in part to implement ecotourism projects inside the national reserve. Following this path, it would be possible to obtain incomes from tourism while carbon prices increase their monetary value as expected. Herein lies the importance of not selling much or all of the carbon capacity for the implementation of carbon projects.

Still, there is a lack of information that needs to be tackled in respect of a detailed sustainability appraisal of possible use options for the AMNR taking new account of Regulating and Cultural ecosystem services. As such, it is likely that the prevailing development model will require reconsideration towards a more integrated land use strategy consistent with ecological integrity. Along these lines, communities and other key stakeholders will need guidance in choosing the best options to achieve sustainable development that may improve their quality of life and the quality of the environment around them.

\section{REFERENCES}

[1] Hein, L., Bagstad, K., Edens, B., Obst, C., De Jong, R., Lesschen, J.P. 2016. Defining ecosystem assetsfor natural capital accounting. PLoS ONE, 11 (11), 1-25. https://doi.org/10.1371/journal.pone.0164460

[2] Arico, S., Bridgewater, P., El-beltagy, A., Harms, E., Program, S., Hepworth, R., Watson, R.T. 2008. Ecosystem change and Human wellbeing.

[3] Farley, J. 2012. Ecosystem services: The economics debate. Ecosystem Services, 1 (1), 40-49.

[4] Palacios-Agundez, I., Onaindia, M., Barraqueta, P., Madariaga, I. 2015. Provisioning ecosystem services supply and demand: The role of landscape management to reinforce supply and promote synergies with other ecosystem services. Land Use Policy, 47, 145- 155. https://doi.org/10.1016/j.landusepol.2015.03.012

[5] Perez-Verdin, G., Sanjurjo-Rivera, E., Galicia, L., Hernandez-Diaz, J.C., Hernandez-Trejo, V., Marquez-Linares, M.A. 2016. Economic valuation of ecosystem services in Mexico: Current status and trends. Ecosystem Services, 21, 6-19. https://doi.org/10.1016/j.ecoser.2016.07.003

[6] Moreno-Mateos, D., Maris, V., Béchet, A., Curran, M. 2015. The true loss caused by biodiversity off sets. Biological Conservation, 192, 552-559. https://doi.org/10.1016/j.biocon.2015.08.016

[7] Kubiszewski, I., Costanza, R., Anderson, S., Sutton, P. 2017. The future value of ecosystem services: Globalscenarios and national implications. Ecosystem Services, 26, 289-301. https://doi.org/10.1016/j.ecoser.2017.05.004

[8] Laurans, Y., Rankovic, A., Billé, R., Pirard, R., Mermet, L. 2013. Use of ecosystem services economic valuation for decision making: Questioning a literature blindspot. Journal of Environmental Management, 119, 208219. https://doi.org/10.1016/j.jenvman.2013.01.008

[9] Hein, L., van Koppen, C.S.A.K., van Ierland, E.C., Leidekker, J. 2016.
Temporal scales, ecosystem dynamics, stakeholders and the valuation of ecosystems services. Ecosystem Services, 21, 109-119. https://doi.org/10.1016/j.ecoser.2016.07.008

[10] Burkhard, B., Kroll, F., Nedkov, S., Müller, F. 2012. Mapping ecosystem service supply, demand and budgets. Ecological Indicators, 21, 17-29. https://doi.org/10.1016/j.ecolind.2011.06.019

[11] Gopal, B. 2016. A conceptual framework for environmental flows assessment based on ecosystem services and their economic valuation. $\begin{array}{llll}\text { Ecosystem } & \text { Services, } & \text { 21, } & \end{array}$ https://doi.org/10.1016/j.ecoser.2016.07.013

[12] Turkelboom, F., Thoonen, M., Jacobs, S., Berry, P. 2015. Ecosystem Service Trade-offs and Synergies. Ecology and Society, 21 (1), 43. https://doi.org/10.13140/RG.2.1.4882.9529

[13] Mukul, S.A., Sohel, M.S.I., Herbohn, J., Inostroza, L., König, H. 2017. Integrating ecosystem services supply potential from future land-use scenarios in protected area management: A Bangladesh case study. Ecosystem Services, 26, 355-364. https://doi.org/10.1016/j.ecoser.2017.04.001

[14] Villamagna, A.M., Angermeier, P.L., Bennett, E.M. 2013. Capacity, pressure, demand, and flow: A conceptual framework for analyzing ecosystem service provision and delivery. Ecological Complexity, 15, 114121. https://doi.org/10.1016/j.ecocom.2013.07.004

[15] Wiggering, H. 2007. Multifunctional Land Use.

[16] Jiang, M., Pang, X., Wang, J., Cao, C. 2018. Islands ecological integrity evaluation using multi sources data. Ocean and Coastal Management, 158 (178), 134-143. https://doi.org/10.1016/j.ocecoaman.2018.03.033

[17] Stürck, J., Schulp, C.J.E., Verburg, P.H. 2015. Spatio-temporal dynamics of regulating ecosystem services in Europe - The role of past and future land use change. Applied Geography, 63, 121-135. https://doi.org/10.1016/j.apgeog.2015.06.009

[18] Burkhard, B., Kandziora, M., Hou, Y., Müller, F. 2014. Ecosystem service potentials flows and demands-concepts for spatial localisation, indication and quantification. Landscape Online, 34 (1), 1-32. https://doi.org/10.3097/L0.201434

[19] Nelson, E., Mendoza, G., Regetz, J., Polasky, S., Tallis, H., Cameron, D.R., Shaw, M.R. 2009. Modeling multiple ecosystem services, biodiversity conservation, commodity production, and tradeoffs at landscape scales. Frontiers in Ecology and the Environment, 7 (1), 4-11. https://doi.org/10.1890/080023

[20] Fisher, B., Bateman, I., Turner, K. 2011. Valuing Ecosystem Services: Benefits, Values, Space and Time. Ecosystem Services Economics (ESE), 11. [21] Rodríguez, J.P., Beard, T.D., Bennett, E.M., Cumming, G.S., Cork, S.J., Dobson, A.P., Peterson, G.D. 2006. Trade-offs across Space, Tim, and Ecosystem Services. Ecology and Society, 11 (1). https://doi.org/10.2307/26267786

[22] Howe, C., Suich, H., Vira, B., Mace, G.M. 2014. Creating win-wins from trade-offs? Ecosystem services for human well-being: A meta-analysis of ecosystem service trade- offs and synergies in the real world. Global $\begin{array}{llll}\text { Environmental } & \text { Change, } & 28 & \text { (1), 263-275. }\end{array}$ https://doi.org/10.1016/j.gloenvcha.2014.07.005

[23] Bukvareva, E., Zamolodchikov, D., Kraev, G., Grunewald, K., Narykov, A. 2017. Supplied, demandedand consumedecosystem services: Prospectsfor nationalassessment in Russia. Ecological Indicators, 78, $351-$ 360. https://doi.org/10.1016/j.ecolind.2017.03.034

[24] Barbier, E.B. 2014. Account for depreciation of natural capital. Nature, 515, 32-33.

[25] Koh, L.P., Ghazoul, J. 2010. Spatially explicit scenario analysis for reconciling agricultural expansion, forest protection, and carbon conservation in Indonesia, 107 (24), 11140- 11144. https://doi.org/10.1073/pnas.1000530107 
[26] Affek, A.N., Kowalska, A. 2017. Ecosystem potentials to provide services in the view of direct users. Ecosystem Services, 26, 183-196. https://doi.org/10.1016/j.ecoser.2017.06.017

[27] Hein, A.L., Edens, B., Bagstad, K., Obst, C. 2015. A perspective on capacity in the context of ecosystem accounting 1,1-10.

[28] De Groot, R.S., Wilson, M.A., Boumans, R.M.J. 2002. A typology for the classification, description and valuation of ecosystem functions, goods and services. Ecological Economics, 41 (3), 393-408. https://doi.org/10.1016/S0921-8009(02)00089-7

[29] Papendiek, F., Ende, H.P., Steinhardt, U., Wiggering, H. 2012. Biorefineries: Relocating biomass refineries to the rural area. Landscape Online, 27 (1), 1-9. https://doi.org/10.3097/L0.201227

[30] Strand, J., Carson, R.T., Ortiz-bobea, A. 2014. A “Delphi Exercise” as a Tool in Amazon Rainforest Valuation, (December) https://doi.org/10.1016/S0921-8009(97)00584-3

[31] Hooper, T., Beaumont, N., Griffiths, C., Langmead, O., Somerfield, P.J. 2017. Assessing the sensitivity of ecosystem services to changing pressures. Ecosystem Services, 24, 160-169. https://doi.org/10.1016/j.ecoser.2017.02.016

[32] König, H.J., Uthes, S., Schuler, J., Zhen, L., Purushothaman, S., Suarma, U., Wiggering, H. 2013. Regional impact assessment of land use scenarios in developing countries using the FoPIA approach: Findings from five case studies. Journal of Environmental Management, 127, S56-S64. https://doi.org/10.1016/j.jenvman.2012.10.021

[33] Saatchi, S.S., Harris, N.L., Brown, S., Lefsky, M., Mitchard, E.T.A., Salas, W. 2011. Benchmark map of forest carbon stocks in tropical regions across three continents, 108 (24). https://doi.org/10.1073/pnas.1019576108

[34] Martel, C., Cairampoma, L. 2012. Cuantificación del carbono almacenado en formaciones vegetales amazónicas en CICRA, Madre de Dios (Perú). Ecología Aplicada, 11 (2), 59-65.

[35] Winrock International. 2006. Carbon Storage in the Los Amigos Conservation Concession, Madre de Dios, Perú, (May).
[36] Willcock, S., Phillips, O.L., Platts, P.J., Balmford, A., Burgess, N.D. Lovett, J.C., Lewis, S.L. $2014 . \quad$ Quantifying andunderstandingcarbonstorageandsequestration withinthe Eastern Arc Mountains of Tanzania, a tropical biodiversity hotspot. Carbon Balance and Management, 9 (1), 2. https://doi.org/10.1186/1750-0680-9-2

[37] Asner, G.P., Powell, G.V.N., Mascaro, J., Knapp, D.E., Clark, J.K., Jacobson, J. 2010. High- resolution forest carbon stocks and emissions in the Amazon, 107 (38), 1-5. https://doi.org/10.1073/pnas.1004875107

[38] Mcfarland, B.J. 2011. Carbon Reduction Projects and the Concept of Additionality. Sustainable Development Law \& Policy, 11 (2), 15-18.

[39] Hamrick, K., Gallant, M. 2017. Unlocking Potential State of the Voluntary Carbon Markets 2017 Supporter Sponsors Initiative for Sustainable Forest Landscapes, 52.

[40] World Bank. 2014. State and Trends of Carbon Pricing https://doi.org/10.1596/978-1- 4648- 0268-3

[41] Hamrick, K., Goldstein, A. 2016. Raising Ambition.

[42] Phillips, O.L., Brienen, R.J.W., Gloor, E., Baker, T.R., Lloyd, J., LopezGonzalez, G., Ricardo, J. 2017. Carbon uptake by mature Amazon forests has mitigated Amazon nations' carbon emissions. Carbon Balance and Management, 12 (1), 1-9. https://doi.org/10.1186/s13021-016-0069-2

[43] Schröter, M., van der Zanden, E.H., van Oudenhoven, A.P.E., Remme, R.P., Serna-Chavez, H.M., de Groot, R.S., Opdam, P. 2014. Ecosystem Services as a Contested Concept: A Synthesis of Critique and CounterArguments. Conservation Letters, 7 (6), 514-523. https://doi.org/10.1111/conl.12091

[44] Isbell, F., Calcagno, V., Hector, A., Connolly, J., Harpole, W.S., Reich, P.B., Loreau, M. 2011. High plant diversity is needed to maintain ecosystem $\begin{array}{llll}\text { services. } & \text { Nature, } & 477 & \text { (7363), }\end{array}$ https://doi.org/10.1038/nature10282

[45] Conservation Strategy Fund. 2018. Conservación Estratégica E impacto económico local del turismo en áreas protegidas del Perú 